\title{
Somatic Embryogenesis in Recalcitrant Plants
}

\author{
Laura Yesenia Solís-Ramos ${ }^{1,2,{ }^{*},}$, Antonio Andrade-Torres ${ }^{3,4}$, \\ Luis Alfonso Sáenz Carbonell ${ }^{3}$, Carlos M. Oropeza Salín ${ }^{3}$ and \\ Enrique Castaño de la Serna ${ }^{1}$ \\ ${ }^{1}$ Unidad de Bioquímica y Biología Molecular de Plantas, \\ Centro de Investigación Científica de Yucatán, (CICY), Mérida, Yucatán, \\ Studies on habanero chilli biotechnology \\ ${ }^{2}$ Escuela de Biología, Universidad de Costa Rica, San Pedro, \\ Genetic Plant Transformation and Biotechnology \\ ${ }^{3}$ Unidad de Biotecnología, Centro de Investigación Científica de Yucatán, (CICY), \\ Mérida, Yucatán, Biotechnological studies on coconut \\ ${ }^{4}$ INBIOTECA- Instituto de Biotecnología y Ecología Aplicada, Universidad Veracruzana, \\ Xalapa, Veracruz, México, Genetic Plant Transformation and Biotechnology \\ 1,3,4México \\ ${ }^{2}$ Costa Rica
}

\section{Introduction}

There are two types of embryogenesis in plants: zygotic and somatic (Figure 1). Zygotic embryogenesis is one of the most important steps in the life cycle of plants. The process begins with double fertilization, followed by determination of the three axes of embryos (longitudinal, lateral, and radial) and morphologic changes of the embryos (globular, heartshaped, and torpedo-shaped; Figure 1). Subsequently, seed storage proteins accumulate in the embryos, and finally, the embryos become desiccated and dormant. These processes are regulated by numerous factors, including phytohormones, enzymes, and other substances related to embryogenesis.

Somatic embryogenesis (SE) is the process by which somatic cells, under induction conditions, generate embryogenic cells, which go through a series of morphological and biochemical changes (Quiróz-Figueroa et al., 2006), that result in the production of bipolar structure without vascular connection with the original tissue. The development of somatic embryos closely resembles the development of zygotic embryos both morphologically and physiologically (Figure 1). The process is feasible because plants possess cellular totipotency where by individual somatic cells can regenerate into a whole plant. Since the first reports on carrot in 1958 (Reinert 1958; Steward et al., 1958), somatic embryogenesis has been reported in various plant species.

In addition to natural in vivo forms embryogenesis (apomixis), there exist at least three ways to induce embryo development from in vitro cultured plant cells: in vitro fertilization, from

${ }^{*}$ Corresponding Author 
microspores and in vitro somatic embryogenesis (Féher et al., 2003). In vitro SE can develop either from callus (indirect SE) or directly from the explant without any intermediate callus stage (direct SE). Somatic embryogenesis is also induced directly, or through callus, in the culture of somatic embryos, and this process is called secondary SE in contrast to primary SE induced from explant cells (Gaj, 2004).

\section{Zygotic Embryogenesis

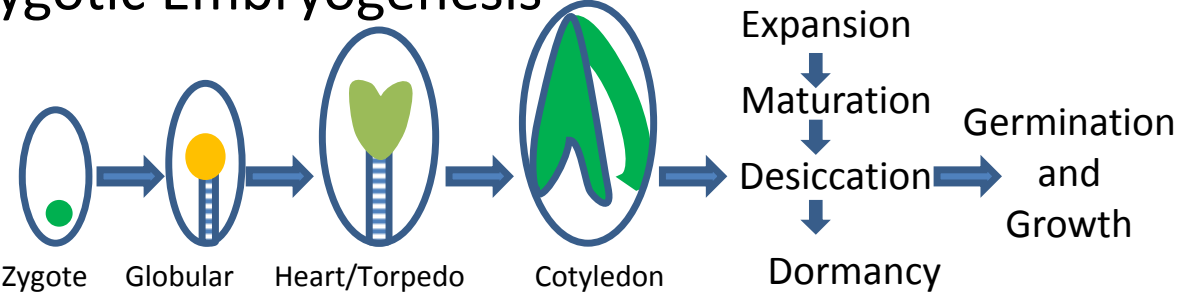 \\ Zygote Globular Heart/Torpedo Cotyledon Dormancy}

\section{Somatic Embryogenesis}

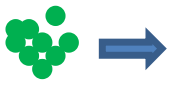

Callus
Globular
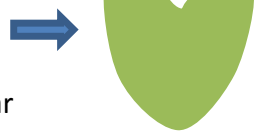

Heart/Torpedo

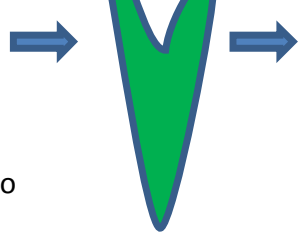

Plantlet
Regeneration

of whole plant

Fig. 1. Zygotic vs somatic embryogenesis. Modified from Zimmerman, 1993.

Somatic embryos originate by two pathways, unicellular or multicellular. When embryos have a unicellular origin, coordinated cell divisions are observed and the embryo sometimes connected to the maternal tissue by a suspensor-like structure. In contrast, multicellularorigin embryos are initially observed as a protuberance, with no coordinated cell divisions observable, and those embryos in contact with the basal area are typically fused to the maternal tissue (Quiroz-Figueroa et al., 2006).

Somatic embryogenesis with a low frequency of chimeras, a high number of regenerates and a limited level of somaclonal variation (Ahloowalia, 1991; Henry et al., 1998) is more attractive than organogenesis as a plant regeneration system (e.g., in genetic transformation, in vitro mutagenesis and selection). However there are several factors that influence the initiation of somatic embryogenesis in plants.

In the context of this paper, in vitro plant recalcitrance is defined as the inability of plant tissue cultures to respond to in vitro manipulations. In its broadest terms, tissue culture recalcitrance also concerns the time-related decline and/or loss of morphogenetic competence and totipotent capacity (Benson, 2000). 


\section{Some factors influencing somatic embryogenesis induction}

The process of acquisition of embryogenic competence by somatic cells must involve reprogramming of gene expression patterns as well as changes in the morphology, physiology, and metabolism of plant cells. Studies on factors controlling in vitro plant morphogenesis are highly important not only for the development of improved regeneration systems, but also for the analysis of molecular mechanisms underlying plant embryogenesis.

In vitro development of cells and tissues depends on different factors such as: genotype, type of plant, age and developmental stage of an explant, physiological state of an explant-donor plant, and the external environment which includes composition of media and physical culture conditions (light, temperature) (Gaj, 2004).

The embryogenic potential is largely defined by the developmental program of the plant as well as by environmental cues (Féher, 2005). The key role of endogenous hormone metabolism affected by genetic, physiological and environmental cues is well accepted in the induction phase of somatic embryogenesis (Jiménez, 2005).

The cells which represent an intermediate state between somatic and embryogenic cells are called competent. Cellular competence is associated with the dedifferentiation of somatic cells that allows them to respond to new developmental signals. It is well accepted that embryogenic competent cells can be morphologically recognized as small, rounded cells with rich cytoplasm and small vacuoles. In this respect they are very similar to meristematic cells or zygotes and this similarity is further emphasized by their asymmetric division (Féher, 2005).

Wounding, high salt concentration, heavy metal ions or osmotic stress positively influenced somatic embryo induction in diverse plant species (reviewed by Dudits et al., 1995). These procedures were accompanied by increased expression of diverse stress-related genes, evoking the hypothesis that somatic embryogenesis is an adaptation process of in vitro cultured plant cells (Dudits et al., 1995).

Endogenous hormone levels however can be considered as major factors in determining the specificity of cellular responses to these rather general stress stimuli (Féher et al., 2003). The temporal and spatial changes in endogenous auxin levels are important factors controlling the embryogenic cell fate (Féher et al., 2003).

Among different external stimuli that induce an embryogenic pathway of development plant growth regulators (PGRs) such as auxins and cytokinins used for in vitro media have been the most frequently considered, as they regulate the cell cycle and trigger cell divisions (Francis and Sorrell, 2001). The high efficiency of 2,4-dichlorophenoxy acetic acid (2,4-D) for induction of embryogenic response found in different in vitro systems and plant species indicates a specific and unique character of this PGR. This synthetic growth regulator and an auxinic herbicide appear to act not only as an exogenous auxin analogue but also as an effective stressor (Gaj, 2004).

The polar transport of auxin in early globular embryos is essential for the establishment of bilateral symmetry during plant embryogenesis. Interference with this transport causes a failure in the transition from axial to bilateral symmetry and results in the formation of embryos with fused cotyledons (Liu et al., 1993). 
The chromatin remodelling plays two major roles during the early stages of somatic embryogenesis. Differentiation requires unfolding of the supercoiled chromatin structure, in order to allow the expression of genes inactivated by heterochromatinization during differentiation, and subsequent chromatin remodelling can result in the specific activation of a set of genes required for embryogenic development (Féher et al., 2003).

Also a wide and complex variety of molecules can now be enlisted, including polysaccharides, amino acids, growth regulators, vitamins, low molecular weight compounds, polypeptides, etc. (Chung et al., 1992). Some such compounds are derived from the cell wall, whereas others originate inside the cells (Quiroz-Figueroa et al., 2006).

\section{Some genes related to somatic embryogenesis}

\subsection{WUSCHEL (WUS)}

WUS is a homeobox gene which encodes a transcription factor that regulates the pool of stem cells in the shoot meristem and is regulated by a feedback loop involving the CLAVATA (CLV) genes (Weigel and Jurgens, 2002; Bhalla and Singh, 2006). WUS expression can be first localized to the shoot meristem in the heart stage embryo, and the shoot meristem of the plant by regulating the stem cell pool can continue to produce organs throughout the life of the plant. The stem cells are specified by a WUS-dependent signal produced in the organizing center cells, which lie below the stem cell niche of the central zone and CLV3 is in turn produced by the stem cells of the central zone (Baurle and Laux, 2005; Reddy and Meyerowitz, 2005). Increases in the number of stem cells lead to an increasing amount of the secreted CLV3 protein, which acts via the CLV1/CLV2 receptor complex to reduce WUS expression and the number of stem cells, thus maintaining a constant pool of stem cells (Weigel and Jurgens, 2002).

\subsection{Baby Boom (BBM)}

The Baby Boom (BBM) gene, which was isolated from microspore embryo cultures of Brassica napus (Boutilier et al., 2002), encodes a transcriptional factor belonging to the AP2/ERF family. BBM expression was observed during zygotic and pollen-derived somatic embryogenesis. The ectopic expression of BBM and Arabidopsis BBM (AtBBM) in transgenic plants induced the formation of somatic embryo-like structures on the edges of cotyledons and leaves, as well as additional pleiotropic phenotypes, including neoplastic growth, phytohormone-free plant regeneration from explants, and abnormal leaf and flower morphology. Therefore, BBM is likely to promote cell proliferation and morphogenesis during embryogenesis (Boutilier et al., 2002).

\subsection{SERK (Somatic Embryogenesis Receptor Kinase)}

Among the genes involved in somatic embryogenesis, Somatic Embryogenesis Receptor Kinases (SERKs) genes has been detected in the early stages of the process, which form a subgroup in the Leucine-Rich Repeat-Receptor-Like Kinases (LRR-RLKs) comprising the largest subfamily of RLKs in plants and are also related to key processes in plant growth (Sharma et al., 2008). 
The first SERK gene was identified in competent cells of carrot (Daucus carota) in vitro cultured (Schmidt et al., 1997), this gene encodes a transmembrane receptor kinase type with leucine-rich repeat (LRR). DcSERK has been considered as a marker of cells competent to form embryos in culture (Schmidt et al., 1997). DcSERK has been found be expressed in somatic and zygotic embryos but in no other plant tissues at very early stages of somatic embryo development, i.e., from the single-cell stage to the globular stage (Schmidt et al., 1997). Genes homologous to DcSERK were isolated from Arabidopsis (AtSERK1), maize (ZmSERK1, ZmSERK2), Medicago truncatula (MtSERK1) (Nolan et al., 2003), Hieracium (HpSERK), Helianthus annuus (Thomas et al., 2004), Oryza sativa (Hu et al., 2005), Theobroma cacao (Santos et al., 2005), Citrus unshui (Shimada et al., 2005), y Solanum tuberosum (Sharma et al., 2008) suggesting the ubiquity of a small family of SERK in all species of plants, in addition to the functional conservation of a specific role in embryogenesis. Their expressions were detected during somatic embryogenesis (Somleva et al., 2000; Baudino et al., 2001; Hecht et al., 2001; Shah et al., 2002; Nolan et al., 2003; Tucker et al., 2003; Thomas et al., 2004), as well as in developing ovules and early-stage embryos of Arabidopsis, Hieracium and maize.

\section{Genetic transformation to abate recalcitrance}

Genetic transformation has proven to be an alternative to abate recalcitrance to in vitro morphogenesis and to increase resistance to pathogenic microorganisms (Cai et al., 2003; Shin et al., 2002; Zuo et al., 2002; Herrera-Estrella et al., 2004). This has been achieved by insertion and over-expression of genes related to the control of morphogenesis, such as the heterologous gene WUSCHEL in Arabidopsis thaliana and Coffea canephora cultures that promoted the transition from vegetative to embryogenic state, and eventually led to somatic embryo formation (Zuo et al., 2002; Arroyo-Herrera et al., 2008). In Capsicum chinense, the induced expression of WUSCHEL in segments of transformed stems began to form globular structures, suggesting that heterologous WUSCHEL was active and involved in the process of morphogenesis (Solís-Ramos et al., 2009). It has been demonstrated in Arabidopsis, that over-expression of a SOMATIC EMBRYOGENESIS RECEPTOR-like KINASE (SERK) gene (AtSERK1) increases the embryogenic competence of callus derived from transformed seedlings 3 to 4 -fold when compared with the wild-type callus (Hecht et al., 2001).

Most of the important crops and grasses are recalcitrant for in vitro culturing, which hampers the development of reliable regeneration techniques. This document is focused in the somatic embryogenesis of recalcitrant plants, showing the particular cases of two plant species: habanero chili (Capsicum chinense Jacq.) and coconut palm (Cocos nucifera L.).

\section{Studies in habanero chili (Capsicum chinense Jacq.)}

\subsection{Introduction}

All chili peppers belong to the genus Capsicum of the Solanaceae family and are important horticultural crops. Members of the Capsicum genus have been shown to be recalcitrant to differentiation and plant regeneration under in vitro conditions, which in turn makes it very difficult or inefficient to apply recombinant DNA technologies via genetic transformation aimed at genetic improvement against pests and diseases (Ochoa-Alejo and RamírezMalagón, 2001). Capsicum chinense Jacq. (habanero chili) (Fig. 2-G), a species of economic 
importance for Mexico is no exception (Santana-Buzzy et al., 2005; López-Puc et al., 2006), and no efficient, reproducible somatic embryogenesis regeneration system has yet been developed for this species. A dependable system is indispensable for their genetic improvement and regeneration of transformed tissue (Solís-Ramos et al., 2009).
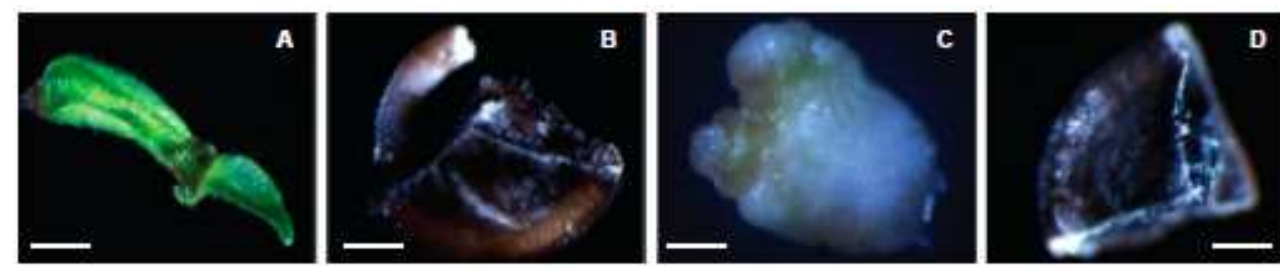

G
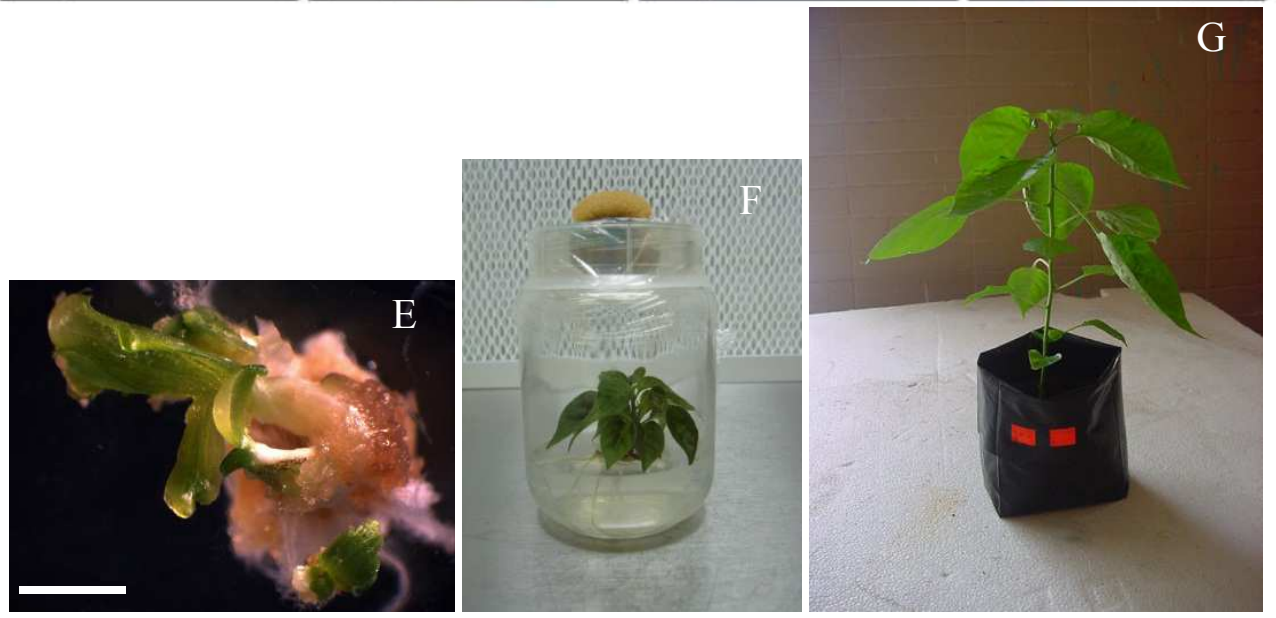

Fig. 2. A to G: Different responses of $C$. chinense explants after induction: A, cotyledon. Bar= $1 \mathrm{~mm}$; B, Zygotic embryo segment with radicle; C, Zygotic embryo segment forming callus; $\mathrm{D}$, Zygotic embryo segment without embryogenic response. Bar $=0.5 \mathrm{~mm}$. E: somatic embryo germinating. Bar= $1 \mathrm{~mm}$. F: seedling obtained from somatic embryo. G: seedling after acclimatization under greenhouse conditions.

\subsection{Indirect somatic embryogenesis protocol}

Direct organogenesis has been the most frequently used morphogenic route for in vitro regeneration of Capsicum plants; however, the major problem faced to achieve this goal has been the failure of elongation of the induced shoot buds (Ochoa-Alejo and RamírezMalagón, 2001). Shoot buds and rosettes are not well formed during the induction step, perhaps because of a lack of true apical meristems (Binzel et al., 1996; Ochoa-Alejo and Ramírez-Malagón 2001; Steinitz et al., 2003).

In recent years, a number of investigators have developed methods in order to increase the efficiency of the somatic embryogenesis process for chili pepper micropropagation via direct somatic embryogenesis (DSE) (Harini and Sita 1993; Binzel et al., 1996; Khan et al., 2006) and 
indirect somatic embryogenesis (ISE) (Binzel et al., 1996; Buyakalaca and Mavituna, 1996, Kintzios et al., 2001, Zapata-Castillo et al., 2007, Solís-Ramos et al., 2010b). Capsicum chinense Jacq. is a recalcitrant species for in vitro morphogenesis, and up to date there is no efficient system for genetic transformation and regeneration of this species via somatic embryogenesis. However an ISE protocol was developed using mature $C$. chinense zygotic embryo segments (ZES) (Solís-Ramos et al., 2010b) (Figure 2 C, E-G). The ZES cultured in semi-solid MS-3R medium (MS medium with $8.9 \mu \mathrm{M}$ NAA, $11.4 \mu \mathrm{M}$ IAA and $8.9 \mu \mathrm{M}$ BAP) developed an embryogenic callus and $8 \%$ of these explants developed somatic embryos (Figure 2-E). Torpedo-stage somatic embryos were detached from the callus and subcultured in semi-solid MS medium without growth regulators, producing a $75 \%$ conversion rate to plantlets with well-formed root tissue. Histological analysis showed the developed structures to have no vascular connection to the source tissue and to be bipolar, confirming that this protocol induced formation of viable somatic embryos from mature $C$. chinense zygotic embryo segments, and seedlings can be obtained (Figure 2 F-G).

\subsection{Endogenous GUS-like activity in C. chinense tissues}

The gene uidA codes for $\beta$-glucuronidase which is utilized as a reporter in plant genetic transformation because it is generally believed that higher plants do not show GUS-like endogenous activity (Jefferson et al., 1987; Martin et al., 1991; Sudan et al., 2006). However, several studies have demonstrated that some plant species show endogenous GUS-like activity in vegetative tissues as well as reproductive organs (Cervera, 2005; Sudan et al., 2006). Therefore, in order to avoid undesirable effects in interpreting genetic transformation results, it is recommended to evaluate potential endogenous GUS-like activity in tissues that will be targeted to genetic transformation by using uidA as a reporter. The $\mathrm{pH}$ of the assay buffer is very critical for detection of the GUS activity in plants. The E. coli-derived GUS has optimum activity at $\mathrm{pH} 7.0$ and hence plant tissues are assayed at neutral $\mathrm{pH}$ after transformation (Sudan et al., 2006).

Segments of mature zygotic embryos of $C$. chinense were used as explants for transient transformation with Agrobacterium tumefaciens LBA4404 (pCAMBIA2301) and C58C1 (pER10W-35S Red) (Solís-Ramos et al., 2010a, Solís-Ramos et al., 2010b). T-DNA in pCAMBIA2301 (Center for the Application of Molecular Biology to International Agriculture, Canberra, Australia) includes a copy of Escherichia coli uidA gene under the control of CaMV35S promoter and the NOS terminator. In this binary vector, uidA gene coding sequence is interrupted by a Castor Bean catalase intron, which has to be removed for eukaryotic expression and prevents bacterial transcriptions of the gene coding sequence. Transient transformation of $C$. chinense explants and plant regeneration were carried out following the protocol previously described by Solís-Ramos et al. (2009). In addition, as a positive control leaves explants of Nicotiana tabacum were transient transformed via A. tumefaciens LBA4404 (pCAMBIA2301), to verify that the protocol used for GUS activity was done properly. Histochemical staining of $C$. chinense explants was carried out following a protocol reported by Jefferson (1987). Presence of blue spots was recorded and interpreted as transient GUS expression (Figure 3). Also the transient expression of red fluorescent protein was detected using a Leica MZFLIII stereoscopic microscope equipped with appropriate filtres $(546 / 10 \mathrm{~nm}, 600 / 40 \mathrm{~nm})$. 
Successful transient transformed C. chinense zygotic embryo explants were achieved with $A$. tumefaciens LBA4404 (pCAMBIA2301) and the bacteria were eliminated with $1 \mathrm{~g} / \mathrm{L}$ cefotaxime and $500 \mathrm{mg} / \mathrm{L}$ timentin (Solís-Ramos et al., 2009). The calli of $C$. chinense transient transformed with pER10W-35S Red (used as control for transformation efficiency) expressed the red fluorescent protein (DsRFP), but not the non-transformed calli (data not shown) (Solís-Ramos et al., 2010a). A screening for endogenous GUS-like activity in C. chinense tissues was performed in phosphate buffer adjusted to $\mathrm{pH}$ 6, 7, 7.5 and 8 . At $\mathrm{pH} 6$ and 7 the $100 \%$ of all samples (vegetative and reproductive tissues) presented endogenous GUS-like activity (Figure 3-C) (Solís-Ramos et al., 2010a). At pH 7.5 no GUS-like activity was observed in all of the petals, root, stem or leaves. However, in septum, stamen and calli some GUSlike activity was observed. A substantial decrease, or even a total absence, of GUS-like activity was observed in phosphate buffer $\mathrm{pH} 8$ in almost all tissue analyzed with an exception for a slight activity in stamens (Figure 3-A) (Solís-Ramos et al., 2010a). Our results of histochemical staining in phosphate buffer $\mathrm{pH} \mathrm{8,} \mathrm{suggest} \mathrm{that} \mathrm{uidA} \mathrm{gene} \mathrm{was} \mathrm{introduced}$ in regenerants of $C$. chinense and $N$. tabacum and the gene was transcriptional active as it can be inferred from the blue stain observed in tissues of regenerated plantlets. The main problem during initial steps of transformation is just to get an assay conditions which can provide an initial screening. This problem has been solved by adjusting the $\mathrm{pH}$ to 8 for $C$. chinense (Solís-Ramos et al., 2010a).
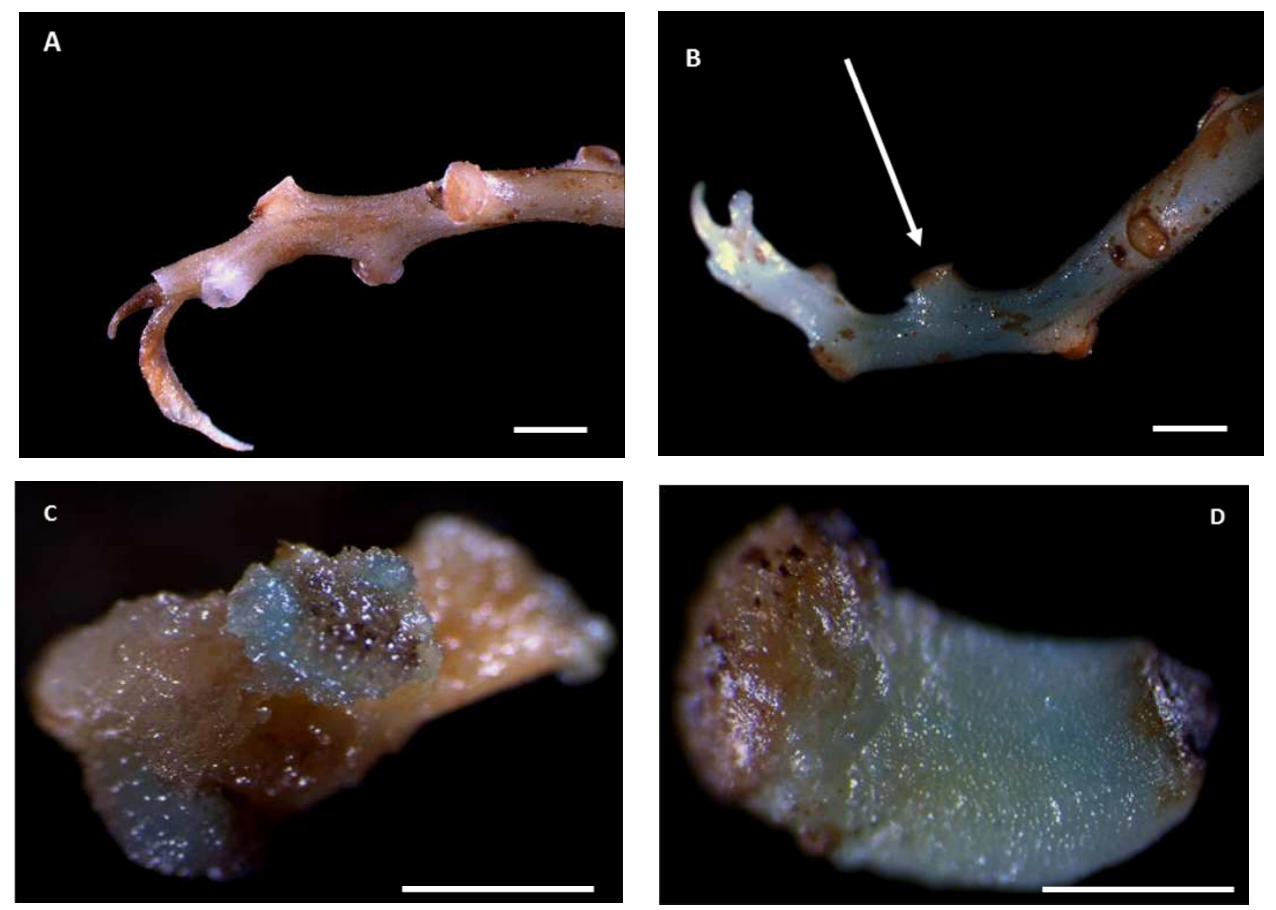

Fig. 3. C. chinense explants showing endogenous GUS-like activity at $\mathrm{pH} 7(\mathrm{C})$, and without endogenous GUS-like activity at $\mathrm{pH} 8$ (A). B and D transformed explants showing GUS expression. A, B bar $=5 \mathrm{~mm}$. C, D bar $=1 \mathrm{~mm}$. 


\subsection{Protocol for genetic transformation}

Habanero chili plants were transformed via Agrobacterium tumefaciens co-cultivation with reporter genes: uiDA, DsRFP, and WUSCHEL (Solís-Ramos et al., 2009, Solís-Ramos et al., 2010a, Solís-Ramos et al., 2010b). WUSCHEL (WUS) has been shown to promote the transition from vegetative to embryogenic state when overexpressed in Arabidopsis thaliana (Zuo et al., 2002). The hypothesis tested is that the genetic transformation of Habanero chili and overexpression of heterologous gene WUS will promotes an embryogenic response in this species (Solís-Ramos et al., 2009). The transformed chimeric plants where used for induction of expression of heterologous gene WUS. After 15 days of induction, the segments of transformed stems begun to form globular structures, and the wild type did not show development, suggesting that heterologus WUS was active and involved in the process of morphogenesis. The induced transformed explants showed the expression of WUS by Northern reverse analysis, and none WUS transcripts had detectable in the wild type. The histological analysis of induced transformed stems showed the development of meristematic nodules and the formation of globular somatic embryos, which presented necrosis after 45 days of in vitro culture, which did not continue development into other embryonic stages or in plants. The results showed that overexpression of gene WUS in stems of Habanero chili promote the formation of embryogenic structures but these stagnate in their growth suggesting that other signals may be need it for induction of proper development in this species (Solís-Ramos et al., 2009). In addition this suggests that WUS encourages the development of undifferentiated tissue in species that may help as an alternative to solve the recalcitrance from this plant species (Solís-Ramos et al., 2009).

\section{Studies for coconut (Cocos nucifera L.) somatic embryogenesis}

\subsection{Introduction}

Coconut (Cocos nucifera L.) is widely distributed throughout the humid tropics where it is cultivated over an estimated twelve million ha. It is a very important perennial crop, since it significantly contributes to food security, improved nutrition, employment and income generation. Coconut is a monospecific palm species consisting of numerous ecotypes and hybrids all possessing desirable agronomic properties. There is a great ethnic diversity in the ways that various coconut resources are produced and used (Foale, 2005). It is often referred to as "the tree of life" because of the many uses that have been developed for all parts of the palm. More recent uses of economic importance include fibre-derived products for the automobile industry; activated charcoal; virgin oil; bottled water; and oil for production of coco-biodiesel. In the Philippines, an industrial plant was launched in 2006 for the production of 75 million liters / year of coco-biodiesel where it is being used as a fuel additive (Lao, 2009). A blend at $2 \%$ coconut oil with diesel has been shown to reduce harmful exhaust emissions (opacity, K value) by as much as 63\% (Lao, 2008).

However, most coconut groves require replanting because of loss due either to palm senescence or to diseases such as lethal yellowing in America (Harrison and Oropeza, 2008), the lethal diseases in Africa (Eden-Green, 1997) and cadang-cadang in Asia (Hanold and Randles, 1991). Unfortunately, improved disease resistant planting materials are scarce and seed propagation does not yield sufficient material to satisfy the rapidly growing demands. 
Therefore, alternative approaches for the propagation of improved planting materials must be considered and in vitro propagation or micropropagation via somatic embryogenesis seems to provide a convenient alternative for the future due to its potential for massive propagation.

Several explants have been tested with diverse results, being the most responsive immature infloresencenes and plumules in increasing order (Blake and Hornung, 1995; Chan et al., 1998; Pérez-Nuñez et al., 2006). For this reason plumules have been more extensively used to improve on the different developmental changes in the process: callogenesis, embryo formation, germination and conversion.

\subsection{In vitro culture of coconut palm}

\subsubsection{Coconut micropropagation using plumule explants}

In order to increase the efficiency of somatic embryogenesis in coconut, two different approaches were evaluated, secondary somatic embryogenesis and multiplication of embryogenic callus. Primary somatic embryos obtained from plumule explants were used as explants and formed both embryogenic callus and secondary somatic embryos. The embryogenic calluses obtained after three multiplication cycles were capable of producing somatic embryos. The efficiency of the system was evaluated in a stepwise process beginning with an initial step for inducing primary somatic embryogenesis followed by three steps for inducing secondary somatic embryogenesis followed by three steps for embryogenic callus multiplication, and finally production of somatic embryos from callus (Pérez-Nuñez et al., 2006). The actual process of somatic embryogenesis by embryogenic callus multiplication and secondary somatic embryogenesis is shown in Figure 4 . The total calculated yield from one plumule was 98,000 somatic embryos (SEs). Comparing this to the yield obtained from primary somatic embryogenesis results in about a 50,000-fold increase (Pérez-Nuñez et al., 2006).

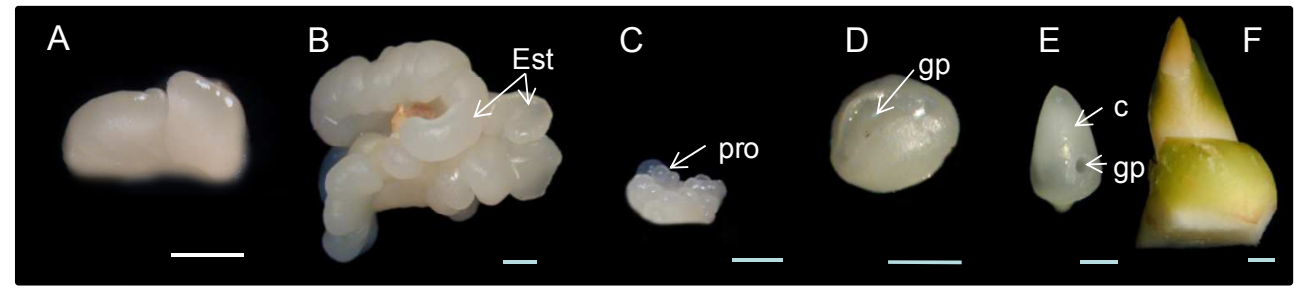

Fig. 4. An embryogenic structure derived from an embryogenic callus used as explant (A), developed an embryogenic callus (B) after 90 days of culture in medium I. After transferring embryogenic callus to medium II, callus with somatic embryos at different stages occurred. Piece of callus with pro-embryos (C), globular embryo (D), coleoptilar embryo (E) and germinating embryo $(\mathrm{F})$. Bar= $1 \mathrm{~mm}$. Coleoptile: [c], germinative pore: [gp], pro-embryo [pro]

This protocol represented an important progress towards practical application by showing a way to improve the efficiency of coconut somatic embryo production. However has still some bottlenecks, as the relative low percentage of formation of embryogenic calli (40- 
$60 \%)$ and calli with somatic embryos (12-24\%) and the low number of somatic embryos formed (2-10) per callus. In order to increase these figures and optimize this protocol to avoid many steps of multiplication, different plant growth regulators and compounds has been tested.

\subsection{Exogenous plant growth regulators}

\subsubsection{Brassinosteroids}

The effect of the brassinosteroid 22(S), 23(S)-homobrassinolide on initial callus, embryogenic callus and somatic embryo formation in coconut plumule explants was tested. The explants were exposed (during a 3 or $7 \mathrm{~d}$ pre-culture) to different concentrations $(0.01,0.1,1,2$ and 4 $\mu \mathrm{M})$ of the brassinosteroid. The explants responded favorably to the brassinosteroid increasing their capacity to form initial callus, embryogenic callus and somatic embryos. The largest amount of somatic embryos formed, 10.8 somatic embryos / explant, was obtained exposing the explants for $3 \mathrm{~d}$ to the brassinosteroid at 0.01 or $0.1 \mu \mathrm{M}$, whereas 3.8 somatic embryos / explant were obtained from untreated explants. Efficiency-wise the overall effect of $\mathrm{HBr}$ increases the total amount of somatic embryos formed per explant 2.8 times (Azpeitia et al. 2003).

\subsubsection{Gibberellic acid}

In some reports of coconut the $\mathrm{GA}_{3}$ is added into the culture medium to promote the germination of somatic embryos (Perera et al., 2009). However the effect of addition of this phytohormome had not been tested on the formation of somatic embryos. The results obtained with $\mathrm{GA}_{3}$ were positive at $0.5 \mu \mathrm{M}$ using the protocol of embryogenic calli multiplication from plumule explants. This concentration promoted 1.5 fold the number of the embryogenic calli forming somatic embryos. The number of somatic embryos per callus also increased, about 5 fold at day 30 (globular embryos) and 2 fold afterwards (coleptilar embryos). Also when the effect of $\mathrm{GA}_{3}$ was evaluated on the germination of somatic embryos, the results were positive. The proportion of calli with germinating embryos was 2 fold higher than in the control treatment with no phytohormone. The number of germinating somatic embryos per callus was also higher under phytohormone treatment, also a 2 fold increase in relation to the control treatment. Therefore, a combined 4 fold increase in the overall number of germinating embryos (Montero-Cortés et al., 2010). Then altogether, the use of $\mathrm{GA}_{3}$ was positive both for the formation of somatic embryos and on their germination, so this could be a very useful approach to improve the performance of coconut micropropagation.

\subsubsection{Uptake of auxins}

\subsubsection{Uptake of 2, 4-D}

As previously reported for inflorescence coconut explants (Oropeza and Taylor, 1994), ${ }^{14} \mathrm{C}$ 2,4-D was taken up by plumular explants. The rate was faster during the first week of culture, and then reduced until reaching a plateau at day 90 . The ${ }^{14} \mathrm{C}-2,4-\mathrm{D}$ concentration in the explants reached its maximum values within the first $20 \mathrm{~d}$ of culture, prior to the appearance of any morphogenic response. It is interesting to note that when radioactivity was steadily taken up, calli were formed and once the calli started to form embryogenic 
structures, uptake practically stopped. This result suggests that the uptake of 2,4-D may be related to the induction of these morphogenic responses.

\subsection{Characterization of genes related to somatic embryogenesis}

\subsubsection{Shoot apical meristem formation and maintaining (KNOX family genes)}

The expression the class I KNOX (KNOTTED-like homeobox) genes seem to play an important role during somatic embryogenesis. In Picea abies overexpression of $H B K 3$, a class I KNOX homeobox gene improves the development of somatic embryos and lines in which $H B K 3$ was down-regulated had reduced ability to produce immature somatic embryos and were not able to complete the maturation processes (Belmonte et al., 2007).

The complete sequences of two KNOX like genes were obtained CnKNOX1 and CnKNOX2. The deduced aminoacid sequence of both showed the highly conserved domains characteristic of KNOX genes. CnKNOX1 showed high homology with KNOX class I proteins. CnKNOX1 expression was detected throughout the embryogenesis process except in somatic embryos at the pro-globular stage, becoming highest in somatic embryos at the coleoptilar stage. No detection of CnKNOX1 expression occurred in calli with aberrant embryos. The addition of gibberellic acid stimulated the expression of CnKNOX1 earlier and the relative expression at all stages was higher. CnKNOX2 expression occurred at all stages peaking at globular stage but gibberellic acid treatment decreased expression (MonteroCortés et al., 2010).

\subsubsection{Somatic embryogenesis (Somatic Embryogenesis Related Kinase-SERK)}

Somatic embryogenesis involves different molecular events including differential gene expression and various signal transduction pathways for activating or repressing numerous genes sets (Chugh and Khurana, 2002). Genes involved in somatic embryogenesis are stage specific and one of the genes identified in early somatic embryogenesis is SOMATIC EMBRYOGENESIS RECEPTOR-LIKE KINASE (DcSERK) that was originally isolated from embryogenic cells in suspension cultures of the dicot Daucus carota (Schmidt et al., 1997). It was found to be expressed in embryogenic but not in non-embryogenic cultures, in cells predicted to be embryogenic, in tissue explants induced by placing them under embryogenic culture conditions, and during somatic embryogenesis up the globular stage. During D. carota zygotic embryogenesis, SERK expression occurred up to the early globular stage, but no expression was found in any other plant tissues, and cells transformed with a SERK promoter-luciferase reporter gene were able to form somatic embryos (Schmidt et al. 1997). Similar findings have been obtained in other dicots. In A. thaliana, the AtSERK1 gene was expressed during the formation of embryogenic cells in culture, early embryogenesis, and in plant in developing ovules, specifically in all cells of the embryo sac up to fertilization, and in all cells after fertilization of the developing embryo until the heart stage (Hecht et al., 2001). A. thaliana seedlings overexpressing AtSERK1 exhibited a three- to fourfold increase in efficiency for initiation of somatic embryogenesis; therefore, an increase in the level of the AtSERK1 conferred embryogenic competence in culture (Hecht et al., 2001).

The complete sequence one SERK like gene was obtained and referred as CnSERK. Predicted sequence analysis showed that CnSERK encodes a SERK protein with the domains reported 
in the SERK proteins in other species. These domains consist of a signal peptide, a leucine zipper domain, five LRR, the Serine- Proline-Proline domain, which is a distinctive domain of the SERK proteins, a single transmembrane domain, the kinase domain with 11 subdomains and the $\mathrm{C}$ terminal region. Analysis of its expression showed that it could be detected in embryogenic tissues before embryo development could be observed. In contrast it was not detected or at lower levels in non-embryogenic tissues, thus suggesting that CnSERK expression is associated with induction of somatic embryogenesis and that it could be a potential marker of cells competent to form somatic embryos in coconut tissues cultured in vitro (Pérez-Nuñez et al., 2009).

\subsection{Protocol for genetic transformation}

We have developed a protocol for genetic transformation of this palm species (AndradeTorres et al., 2011); evaluating reporter genes, transformation methods, and conditions for the use of antibiotics to select transformed plant cells. The gene uidA was first used for $A$. tumefaciens mediated transformation of coconut embryogenic calli. However, endogenous GUS-like activity was found in calli not co-cultured with bacteria. Then essays for Agrobacterium-mediated transformation were developed using green and red fluorescent genes. Both genes are suitables as reporter genes for coconut transformation. In order to establish a protocol for coconut genetic transformation, an approach was used that combined biobalistics to generate micro-wounds in explants, vacuum infiltration and coculture with A. tumefaciens (C58C1+ pER10W-35SRed containing the embryogenesis related gene WUSCHEL). Calli treated with the combined protocol showed red fluorescence with greater intensity and greater area than calli treated with either biobalistics or infiltration, followed by bacteria co-culture. PCR amplification of DNA extracts from transformed embryogenic callus produced a band with the expected size using WUSCHEL primers (862 bp). No band was obtained using the VirE2 primers. This is the first report of transient genetic transformation of $C$. nucifera and it is the first step toward a protocol that will be useful for the study of the role of genes of interest and for practical applications, such as the improvement of coconut micropropagation via somatic embryogenesis (Andrade-Torres et al., 2011).

\section{Conclusions and perspectives}

The majority of the mechanisms that regulate plant embryogenesis still remain to be clarified. In the higher plants, some genes and factors related to important mechanisms of embryogenesis are plant-specific. The availability of model systems of plant somatic embryogenesis has created effective tools for examining the details of plant embryogenesis. However, studies that used no model plants for somatic embryogenesis systems also revealed the molecular mechanisms in charge of controlling the expression of some genes during somatic embryogenesis, and with practical applications. So the molecular mechanisms of plant embryogenesis might be clarified by experiments using somatic and zygotic embryogenesis either from model or not model plants.

Numerous protocols on successful somatic embryogenesis induction and plant regeneration in different plant species, published last years, suggest that nowadays SE can be achieved for any plant provided that the appropriate explant and culture treatment are employed 
(Gaj, 2004). A prerequisite for the successful establishment of a SE system is a proper choice of plant material -the explants being a source of competent cells, and, on the other hand, determination of physical and chemical factors which switch on their embryogenic pathway of development (Gaj, 2004).

The process of acquisition of embryogenic competence by somatic cells must involve reprogramming of gene expression patterns as well as changes in the morphology, physiology, and metabolism (Namasivayam, 2007). These alterations reflect dedifferentiation, activation of cell division and a change in cell fate.

Although few genes have been associated with embryogenesis induction, the search for genes involved in embryogenesis, such as SERK (Hecht et al., 2001), LEC (Lotan et al., 1998; Stone et al., 2001), BABY BOOM (Boutilier et al., 2002), WUSCHEL (Zuo et al., 2002), and PICKLE (Ogas et al., 1999), is a major field of research today (Quiroz-Figueroa et al., 2006).

The characterization and functional analysis of protein markers for somatic embryogenesis offer the possibility of determining the embryogenic potential of plant cells in culture long before any morphological changes have taken place, and of gaining further information on the molecular basis of induction and differentiation of plant cells (Tchorbadjieva et al., 2005).

The genetic transformation is certainly an important goal to facilitate genetic improvement against several diseases caused by phytopathogenic fungi, bacteria, and viruses, as well as for improvement against different pests (Ochoa-Alejo and Ramírez-Malagon, 2001). However, development of a reproducible tissue culture regeneration protocol is the first step in utilizing the power and potential of this new technology. The system established for Capsicum chinense is a promising alternative for cell or transformed plant regeneration through indirect somatic embryogenesis, and may contribute to genetic improvement of $C$. chinense Jacq. by incorporating reporter and interest genes (Solís-Ramos et al. 2009; SolísRamos et al, 2010a; Solís-Ramos et al., 2010b).

The protocol for micropropagation of coconut from plumule explants based on embryogenic callus multiplication provides an option not available before for massive propagation of coconuts (Figure 5). However, although it allows the propagation of the progenie of known selected palms, it cannot be used for the cloning of palm individuals with known desirable agronomic traits. On the other hand, the recent developments to obtain embryogenic callus and somatic embryos from immature ovary and anther explants (Perera et al., 2007; 2008; 2009), provide an opportunity to try to use these calli as a source of explants (the embryogenic structures) an integrate them into the callus multiplication scheme used with plumule explants. This has already been attempted in CICY using also floral tissue explants, but in this case rachillae slices from immature inflorescences (Oropeza and Chan, unpublished results). The callus obtained was tested for multiplication and although it responded poorly at the beginning though a series of multiplications the percentage of callus formation from embryogenic structure explants was above $40 \%$. Therefore, although preliminary, this is a very promising result that shows that massive propagation from somatic tissue explants from adult plants is attainable in the near future. Finally we should continue with the studies to understand somatic embryogenesis in coconut. The study of genetic control is central for this purpose; therefore it is very important to learn more about the role of those genes that have been isolated and to extend the study to other genes and 
components of the genetic control of somatic embryogenesis. The study of these processes, will allow us not only to understand a phenomenon but it might open new avenues of opportunity for further improvement for a more efficient and better quality clonal propagation of coconuts.

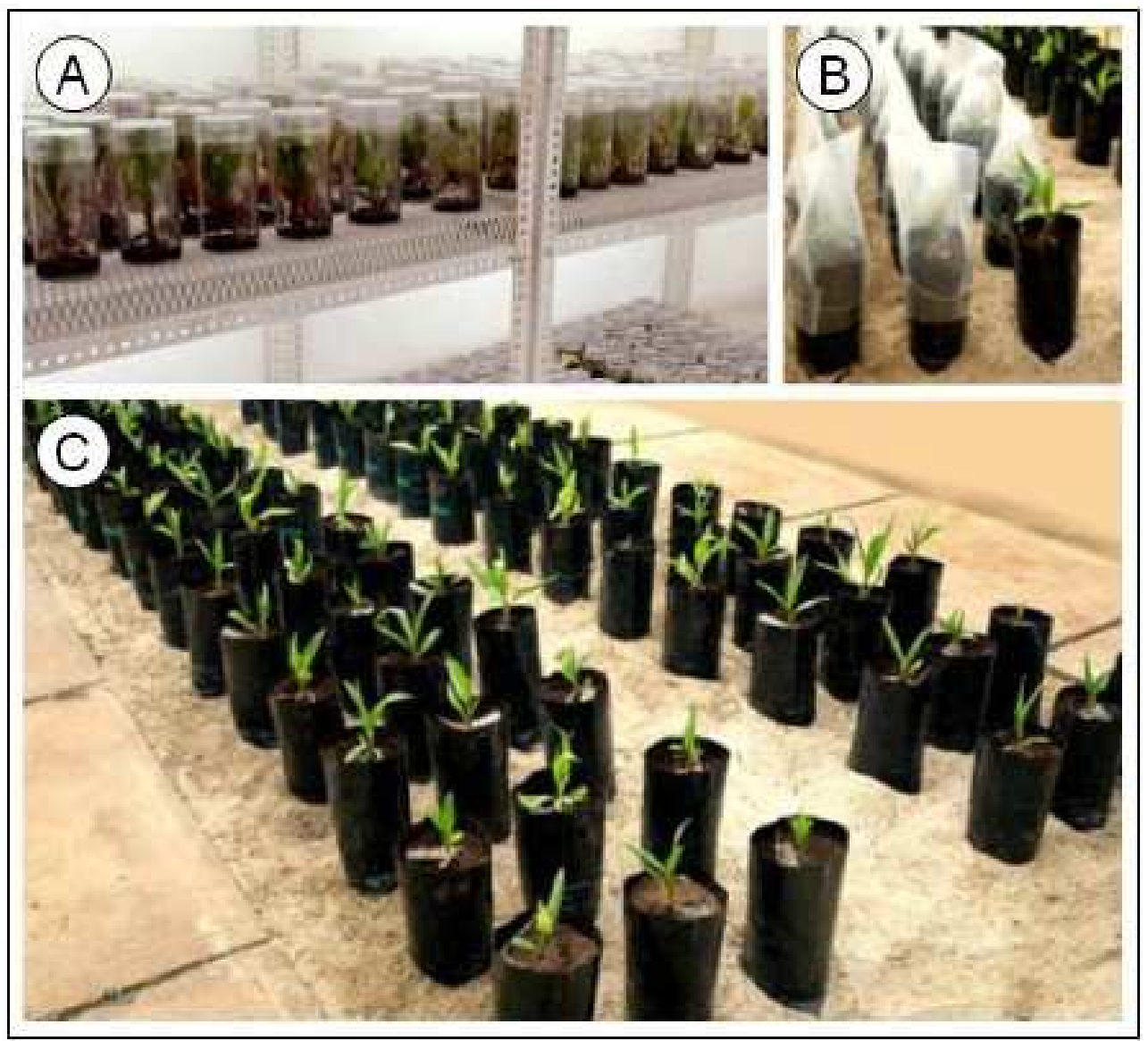

Fig. 5. Final stages of micropropagation process of coconut palm. (A) In vitro plantlets ready to be transferred to ex-vitro conditions. (B) Acclimatization of plantlets in greenhouse covered with transparent perforated bags and (C) plantlets ready to be transferred to field conditions.

\section{Acknowledgments}

Laura Solís-Ramos thanks the Ph.D. fellowship from Dirección de Intercambio Académico de la Secretaría de Relaciones Exteriores (SRE), Mexico (Academic Exchange Office of the Secretariat of Foreign Affairs, Mexico) and Centro de Investigación Científica de Yucatán 
(CICY) for facilities and laboratory support. A. Andrade-Torres thanks to CONACYT for the Ph.D. scholarship (204774), and Universidad Veracruzana for the support through the Dirección General de Desarrollo Académico (DGDA) and PROMEP (UV-491). The authors would like to thank to V. Hocher and J-L. Verdeil IRD/CIRAD Montpellier, France respectively, where the isolation of $C n K N O X$ was carried out. Partial funding of the research reported here was from CONACyT, México (Grant no. 43834-Z).

\section{Abbreviations}

SE: somatic embryogenesis

ZES: zygotic embryo segments.

MS: Murashige \& Skoog medium (1962)

BAP, 6-benzylaminopurine

NAA: naphthaleneacetic acid

IAA: indoleacetic acid

ISE: indirect somatic embryogenesis

MS-3R: MS medium with BAP+IAA+NAA

DsRFP: Red fluorescent protein

GUS: $\beta$-glucuronidase (gene uidA)

$\mathrm{pH}$ : hydrogen potential

2, 4-D: 2, 4-dichlorophenoxyacetic acid

$\mathrm{GA}_{3}$ : gibberellic acid

\section{References}

[1] Andrade-Torres, A., C. Oropeza, L. Sáenz, T. González-Estrada, J. E. Ramírez-Benítez, K. Becerril, J. L. Chan, and L. C. Rodríguez-Zapata. 2011. Transient genetic transformation of embryogenic callus of Cocos nucifera L. Biologia. 66 (5):790-800.

[2] Ahloowalia BS. 1991. Somatic embryos in monocots. Their genesis and genetic stability. Rev. Cytol. Biol. Veget-Bot. 14: 223-235.

[3] Arroyo-Herrera A. Ku-González A. Canche-Moo R. Quiróz-Figueroa F.R. Loyola Vargas V. Rodríguez Zapata L.C. Burgeff D’Hondt C. Suárez-Solís V.M. \& Castaño E. 2008. Expression of WUSCHEL in Coffea canephora causes ectopic morphogenesis and increases somatic embryogenesis. Plant Cell Tiss. Org. Cult. 94: 171-180.

[4] Azpeitia A, Chan J L, Sáenz L, Oropeza C. 2003. Effect of 22(S), 23(S)-homobrassinolide on somatic embryogenesis in plumule explants of Cocos nucifera (L.) Cultured in vitro. J of Hort Sci and Biotech. 78: 591-596. 
[5] Baudino S, Hansen S, Brettschneider R, Hecht VRG, Dresselhaus T, Lorz H, Dumas C, Rogowsky PM. 2001. Molecular characterization of two novel maize LRR receptorlike kinases, which belong to the SERK gene family. Planta 213:1-10.

[6] Baurle, I. and Laux, T. 2005. Regulation of WUSCHEL transcription in the stem cell niche of the Arabidopsis shoot meristem. Plant Cell 17: 2271-2280.

[7] Belmonte MF, Tahir M, Schroeder D, Stasolla C. 2007. Overexpression of HBK3, a class I KNOX homeobox gene, improves the development of Norway spruce (Picea abies) somatic embryos. J Exp Bot 58: 2851-2861.

[8] Benson, E. 2000. Special Symposium: In vitro Plant recalcitrance do free radicals have a role in plant tissue culture recalcitrance. In vitro Cell. Dev. Biol.-Plant. 36: 163-170.

[9] Bhalla, P. L. and Singh, M. B. 2006. Molecular control of stem cell maintenance in shoot apical meristem. Plant Cell Rep. 25:249-256.

[10] Binzel ML, Sankhla N, Joshi S, Sankhla D. 1996. Induction of direct somatic embryogenesis and plant regeneration in pepper (Capsicum annuum L.). Plant Cell Reports 15: 536-540.

[11] Blake J and Hornung R. 1995. Somatic embryogenesis in coconut (Cocos nucifera L.) In: Jain S, Gupta P, Newton R (eds). Somatic Embryogenesis in Woody Plants, v. 2. Kluwer Academic Publishers Dordrecht pp 327-340.

[12] Boutilier, K.; Offringa, R.; Sharma, V. K.; Kieft, H.; Ouellet, T.; Zhang, L. M.; Hattori, J.; Liu, C. M.; van Lammeren, A. A. M.; Miki, B. L. A.; Custers, J. B. M.; Campagne, M. M. V. 2002. Ectopic expression of BABY BOOM triggers a conversion from vegetative to embryonic growth. Plant Cell 14:1737-1749.

[13] Buyukalaca S, Mavituna F. 1996. Somatic embryogenesis and plant regeneration of pepper in liquid media. Plant Cell, Tissue and Organ Culture 46: 227-235.

[14] Cai, W-Q, Fang, X., Shang, HS, Wang, X. and Mang, K.Q. 2003. Development of CMVand TMV resistant transgenic chilli pepper: field performance and biosafety assessment. Molecular Breeding. Vol: 11. pp: 25-35.

[15] Cervera M. 2005. Histochemical and fluorometric assays for uidA (GUS) gene detection. Chapter 14. In: PEÑA, Leandro ed. Transgenic plants: Methods and protocols. Humana Press. 286: 203-213.

[16] Chan JL, Sáenz L, Talavera C, Hornung R, 1 Robert M, Oropeza C. 1998. Regeneration of coconut (Cocos nucifera L.) from plumule explants through somatic embryogenesis. Plant Cell Rep 17:515-521

[17] Chugh A. and P. Khurana. 2002. Gene expression during somatic embryogenesis recent advances. Current Science. 83 (6): 715-730.

[18] Chung W, Pedersen H, Chin C-K. 1992. Enhanced somatic embryo production by conditioned media in cell suspension cultures of Daucus carota. Biotechnol Lett. 14: 837-840

[19] Dudits D, Gyugyey J, Bugre L, Bakó L. 1995. Molecular biology of somatic embryogenesis. In: Thorpe TA (ed) In vitro Embryogenesis in Plants. pp: 267-308. Kluwer Academic Publisher, Dordrecht.

[20] Eden-Green SJ. 1997. History and World distribution of lethal yellowing-like diseases of palms. In: Eden-Green SJ, Ofori F (eds). Proceeding of an International 
Workshop on Lethal Yellowing Diseases of Coconut, Elmina, Ghana, November, 1995. Natural Resources Institute, Chatham, UK. pp 9-25.

[21] Fehér A, Pasternak TP, Dudits D. 2003. Review of Plant Biotechnology and Applied Genetics. Transition of somatic plant cells to an embryogenic state. Plant Cell, Tissue and Organ Culture 74: 201-228.

[22] Fehér A. 2005. Why Somatic Plant Cells Start to form Embryos? In. Mujib A., Samaj J. (eds). Plant Cell Monographs (2). Somatic Embryogenesis. Springer-Verlag Berlin Heidelberg. 85-101.

[23] Foale M. 2005. An introduction to the coconut palm. In: Batugal P, Ramanatha V, Rao GP, Oliver J (eds.). Coconut Genetic Resources. International Plant Genetic Resources Institute - Regional Office for Asia, the Pacific and Oceania (IPGRIAPO), Serdang, Selangor DE, Malaysia. pp 1-8.

[24] Francis D. and Sorrell D.A. 2001. The interference between the cell cycle and plant growth regulators: a mini review. Plant Growth Regul. 33: 1-12.

[25] Gaj MD. 2004. Factors influencing somatic embryogenesis induction and plant regeneration with particular reference to Arabidopsis thaliana (L.) Heynh. Plant Growth Regulation 43: 27-47.

[26] Hanold D and Randles JW. 1991. Detection of coconut cadang-cadang viroid-like sequences in oil and coconut palm and other monocotyledons in the south-west Pacific. Ann of Appl Biol 118: 139-151.

[27] Harini I, Sita L. 1993. Direct somatic embryogenesis and plant regeneration from inmature embryos of chilli (Capsicum annuum L.). Plant Science 89: 107-112.

[28] Harrison NA and Oropeza C. 2008. Phytoplasmas associated with coconut lethal yellowing. In: Harrison NA, Rao GP and Marcone C (eds). Characterization, Diagnosis and Management of Phytoplasmas. Studium Press LLC, Houston, USA pp: 219-248.

[29] Hecht V, Vielle-Calzada J-P, Hartog MV, Schmidt Ed DL, Boutilier K, Grossniklaus Ueli, de Vries SC. 2001. The Arabidopsis SOMATIC EMBRYOGENESIS RECEPTOR KINASE 1 Gene is expressed in developing ovules and embryos and embryo and enhances embryogenic competence in culture. Plant Physiol 127:803-816.

[30] Hecht V, Vielle-Calzada JP, Hartog MV, Schmidt DL, Boutilier K, Grossniklaus U, Vries SC. 2001. The Arabidopsis SOMATIC EMBRYOGENESIS RECEPTOR KINASE 1 Gene is expressed in developing ovules and embryos and enhances embryogenic competence in culture. Plant Physiology, november. 127: 803-816.

[31] Henry RJ. 1998. Molecular and biochemical characterization of somaclonal variation. In: Jain SM, Brar DS \& Ahloowalia BS (eds) Somaclonal Variation and Induced Mutations in Crop Improvement (pp 485-499). Kluwer Academic Publishers, Dordrecht.

[32] Herrera-Estrella, L., Simpson, J., and Martínez-Trujillo, M. 2004. Transgenic Plants. An historical perspective. In: Peña, L. Transgenic Plants. Methods and Protocols. Humana Press. 286. Pp.: 3-31.

[33] Hu H, Xiong L, Yang Y. 2005. Rice SERK1 gene positively regulates somatic embryogenesis of cultured cell and host defense response against fungal infection. Planta 222:107-117. 
[34] Jefferson R. 1987. Assaying chimeric genes in plants: the GUS gene fusion system. Plant Molecular Biology Reporter, December 5 (4): 387-405.

[35] Jiménez VM. 2005. Involvement of plant hormones and plant growth regulators on in vitro somatic embryogenesis. Plant Growth Regulation. 47:91-110.

[36] Khan H., Siddique I, Anis, M. 2006. Thidiazuron induced somatic embryogenesis and plant regeneration in Capsicum annuum. Brief communication. Biologia Plantarum, 50 (4): 789-792.

[37] Kintzios S., Drossopoulos J, Lymperopoulos CH. 2001. Effect of vitamins and inorganic micronutrients on callus growth and somatic embryogenesis from leaves of chilli pepper. Plant Cell, Tissue and Organ Culture, 67: 55-62.

[38] Lao DA. 2008. Coco-biodiesel more than a diesel replacement. Bioenergy Forum, Bangkok, April 2008.

[39] Lao DA. 2009. Coco-biodiesel in the Philippines. In: Coconut Philippines published by Asia Outsourcing

[40] Liu C, Xu Z, Chua Nh. 1993. Auxin Polar Transport is essential for the establishment of bilateral symmetry during early plant embryogenesis. The Plant Cell. 5: 621-630.

[41] López-Puc G, Canto-Flick A, Barredo-Pool F, Zapata-Castillo P, Peniche-Montalvo M, Barahona-Pérez F, Iglesias-Andreu, Santana-Buzzy N. 2006. Direct somatic embryogenesis: a highly efficient protocol for in vitro regeneration of habanero pepper (Capscium chinense Jacq.). HortScience 41(7):1645-1650.

[42] Lotan T, Ohto M, Yee MK, West MA, Lo R, Kwong RW, Yamagishi K, Fischer RL, Goldberg RB, Harada JJ. 1998. Arabidopsis LEAFY COTYLEDON 1 is sufficient to induce embryo development in vegetative tissue. Cell. 93: 1195-1205.

[43] Martin T, Wohner RV, Hummel S, Willmitzer L and Frommer WB.1991. The GUS reporter system as a tool o study plant gene expression. In: GALLAGER, S. ed. GUS protocols. Academic Press, Inc. California. pp. 23-43.

[44] Montero-Córtes M, Sáenz L, Córdova I, Quiroz A, Verdeil J-L, Oropeza C 2010. GA3 stimulate the formation and germination of somatic embryos and the expression of a KNOTTED-like homeobox gene of Cocos nucifera (L.) Plant Cell Rep 29: 1049-1059

[45] Namasivayam P. 2007. Acquisition of embryogenic competence during somatic embryogenesis. Review paper. Plant Cell Tiss Organ Cult. 90: 1-8. DOI $10.1007 /$ s11240-007-9249-9

[46] Nolan KE, Irwanto RR, Rose RJ. 2003. Auxin up-regulates MtSERK1 expression in both Medicago truncatula root-forming and embryogenic cultures. Plant Physiol 133:218-230.

[47] Ochoa-Alejo N and Ramírez-Malagon, R. 2001. In vitro chili pepper biotechnology. Invited review. In vitro Cell. Dev. Biol-Plant. 37: 701-729. DOI: 10.1079/IVP2001216.

[48] Ogas J, Kaufmann S, Henderson J, Somerville C. 1999. PICKLE is a CHD3 chromatinremodeling factor that regulates the transition from embryogenic to vegetative development in Arabidopsis. Proc Natl Acad Sci USA. 96: 13839-13844.

[49] Oropeza C and Taylor HF. 1994. Uptake of 2,4-D in coconut (Cocos nucifera L.) explant. In: Lumsden PJ, Nicholas JR, Davies WJ (eds). Physiology, growth and development of plant in culture. Kluwer Academics Publishers, The Netherlands pp 284-288. 
[50] Perera PIP, Hocher V, Verdeil JL, Doulbeau S, Yakandawala DMD, Weerakoon LK. 2007. Unfertilized ovary: a novel explant for coconut (Cocos nucifera L.) somatic embryogenesis. Plant Cell Rep 26: 21-28.

[51] Perera PIP, Perera L, Hocher V, Verdeil JL, Yakandawala DMD, Weerakoon LK. 2008. Use of SSR markers to determine the anther-derived homozygous lines in coconut. Plant Cell Rep 27: 1697-1703.

[52] Perera PIP, Yakandawala DMD, Hocher V, Verdeil J-L, Weerakoon LK. 2009. Effect of growth regulators on microspore embryogenesis in coconut anthers. Plant Cell Tiss Org Cult 96:171-180.

[53] Pérez-Nuñez MT, Chan JL, Sáenz L, González T, Verdeil JL, Oropeza C. 2006. Improved somatic embryogenesis from Cocos nucifera (L.) plumule explants. In Vitro Cell Dev Biol Plant 42:37-43.

[54] Pérez-Núñez MT. Souza R. Sáenz L. Chan J.L. González T. Zúñiga J.J. \& Oropeza C. 2009. Detection of a SERK-like gene in coconut in vitro cultures and analysis of its expression during the formation of embryogenic callus and somatic embryos. Plant Cell Rep. 28: 11-19.

[55] Quiroz-Figueroa F., Rojas-Herrera R, Galaz-Avalos RM, Loyola-Vargas VM. 2006. Embryo production through somatic embryogenesis can be used to study cell differentiation in plants. Review paper. Plant Cell Tiss Organ Cult. 86: 285-301. DOI 10.1007/s11240-006-9139-6

[56] Reddy, G. V. and Meyerowitz, E. M. 2005. Stem-cell homeostasis and growth dynamics can be uncoupled in the Arabidopsis shoot apex. Science 310:663-667.

[57] Reinert J. 1958. Untersuchungen über die Morphogenese an Gewebekulturen. Ber Dtsch Bot Ges 71: 15.

[58] Santana-Buzzy N, Canto-Flick A, Barahona-Pérez F, Montalvo-Peniche MC, ZapataCastillo P, Solís-Ruíz A, Zaldívar-Collí A, Gutiérrez-Alonso O, Miranda-Ham L. 2005. Regeneration of habanero pepper (Capsicum chinense Jacq) via organogenesis. HortScience 40(6): 1829-1831.

[59] Santos MD, Romano E, Yotoko KSC, Tinoco MLP, Dias BBA, Aragao FJL. 2005. Characterization of the cacao somatic embryogenesis receptor-like kinase (SERK) gene expressed during somatic embryogenesis. Plant Sci 168:723-729.

[60] Schmidt EDL, Guzzo F, Toonen MAJ, de Vries SC. 1997. A leucine rich repeat containing receptor-like kinase marks somatic plant cells competent to form embryos. Development 124:2049-2062.

[61] Schmidt EDL, Guzzo F, Toonen MAJ, de Vries SC. 1997. A leucine-rich repeat containing receptor-like kinase marks somatic plant cell competent to form embryos. Development 124:2049-2062.

[62] Shah, K.; Russinova, E.; Gadella, T. W. J.; Willemse, J.; de Vries, S. C. 2002. The Arabidopsis kinase-associated protein phosphatase controls internalization of the somatic embryogenesis receptor kinase 1. Genes Dev. 16:1707-1720.

[63] Sharma, S.K., S. Millam, I. Hein and G.J. Bryan. 2008. Cloning and molecular characterization of a potato SERK gene transcriptionally induced during initiation of somatic embryogenesis. Planta. 228: 319-330. 
[64] Shimada T, Hirabayashi T, Endo T, Fujii H, Kita M, Omura M. 2005. Isolation and characterization of the somatic embryogenesis receptor-like kinase gene homologue (CitSERK1) from Citrus unshui Marc. Sci Hortic 103: 233-238.

[65] Shin R., Han J-H., Lee G.J., and Peak, K.H. 2002. The potencial use of viral coat protein genes as transgene screening marker and multiple virus resistance of pepper plants coexpressing coat proteins of cucumber mosaic virus and tomato mosaic virus. Transgenic Reseach. 11: 215-219.

[66] Solís-Ramos L.Y., González-Estrada T., Nahuath-Dzib S., Rodríguez-Zapata, L., Castaño E. 2009. Overexpression of WUSCHEL in C. chinense causes ectopic morphogenesis. Plant Cell, Tissue and Organ Culture. DOI: 10.1007/s11240-008-9485-7. 96:279-287.

[67] Solís-Ramos LY, González-Estrada T, Andrade-Torres A, Godoy-Hernández G, Castaño de la Serna E. 2010a. Endogenous GUS-like activity in Capsicum chinense Jacq. Electronic Journal of Biotechnology. July 15, 13 (4). DOI: 10.2225/vol13-issue4fulltext-3.

[68] Solís-Ramos LY, Nahuath-Dzib S, Andrade-Torres A, Barredo-Pool F, González-Estrada T, Castaño de la Serna E. 2010b. Indirect somatic embryogenesis and morphohistological analysis in Capsicum chinense. Section Cellular and Molecular Biology. Biologia. 65(3): 504-511. DOI: 10.2478/s11756-010-0049-z.

[69] Somleva MN, Schmidt EDL, de Vries SC. 2000. Embryogenic cells in Dactylis glomerata L. (Poaceae) explants by cell tracking and by SERK expression. Plant Cell Rep 19:718-726.

[70] Steinitz B., Kusek M., Tabib Y., Paran I. \& Zelcer A. 2003 Pepper (Capsicum annuum L.) regenerates obtained by direct somatic embryogenesis fail to develop a shoot. In vitro Cell. Dev. Biol. Plant 39: 296-303.

[71] Steward FC, Mapes MO, Mears K .1958. Growth and organized development of cultured cells. II. Organization in cultures grown from freely suspended cells. Am J Bot 45: 705-708

[72] Stone SL, Kwong LW, Yee KM, Pelletier J, Lepiniec L, Fischer RL, Goldberg RB, Harada JJ (2001) LEAFY COTYLEDON2 encodes a B3 domain transcription factor that induces embryo development. Proc Natl Acad Sci USA 98: 11806-11811.

[73] Suda Ch, Prakash S, Bhomkar P, Jain S and Bhalla-Sarin, N. 2006. Ubiquitous presence of $\beta$-glucuronidase (GUS) in plants and its regulation in some model plants. Planta, September 224 (4): 853-864.

[74] Tchorbadjieva M, Kalmukova R, Pantchev I, Kyurkchiev S. 2005. Monoclonal antibody against a cell wall marker protein for embryogenic potential of Dactylis glomerata $\mathrm{L}$. suspension cultures. Planta 222:811-819.

[75] Thomas C, Meyer D, Himber C, Steinmetz A. 2004. Spatial expression of a sunXower SERK gene during induction of somatic embryogenesis and shoot organogenesis. Plant Physiol Biochem 42:35-42.

[76] Tucker, M. R.; Araujo, A. -C. G.; Paech, N. A.; Hecht, V.; Schmidt, E. D. L.; Rossell, J. -B.; de Vries, S. C.; Koltunow, A. M. G. 2003. Sexual and apomictic reproduction in Hieracium subgenus Pilosella are closely interrelated developmental pathways. Plant Cell 15:1524-1537.

[77] Weigel, D. and Jurgens, G. 2002. Stem cells that make stems. Nature 415: 751-754. 
[78] Zapata-Castillo P, Canto-Flick A, López-Puc G, Solís-Ruíz A, Pérez-Barahona F, Iglesias-Andreu L, Santana-Buzzy N. 2007. Somatic embryogenesis in Habanero pepper (C. chinense Jacq.) from cell suspensions. Hort Science.

[79] Zuo J, Niu QW, Frugis G, Chua N.H. 2002. The WUSCHEL gene promotes vegetativeto-embryonic transition in Arabidopsis. The plant Journal 30(3): 349-359. doi: 10.1046/j.1365-313X.2002.01289.x. 


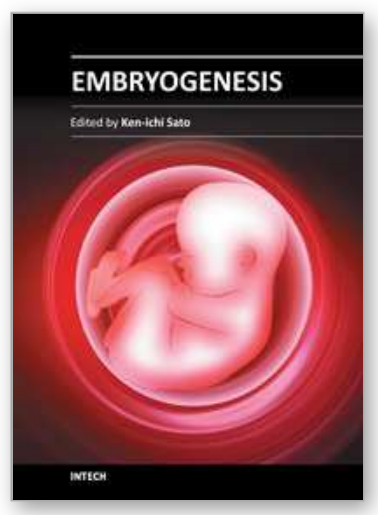

\author{
Embryogenesis \\ Edited by Dr. Ken-Ichi Sato
}

ISBN 978-953-51-0466-7

Hard cover, 652 pages

Publisher InTech

Published online 20, April, 2012

Published in print edition April, 2012

The book "Embryogenesis" is a compilation of cutting edge views of current trends in modern developmental biology, focusing on gametogenesis, fertilization, early and/or late embryogenesis in animals, plants, and some other small organisms. Each of 27 chapters contributed from the authorships of world-wide 20 countries provides an introduction as well as an in-depth review to classical as well as contemporary problems that challenge to understand how living organisms are born, grow, and reproduce at the levels from molecule and cell to individual.

\title{
How to reference
}

In order to correctly reference this scholarly work, feel free to copy and paste the following:

Laura Yesenia Solís-Ramos, Antonio Andrade-Torres, Luis Alfonso Sáenz Carbonell, Carlos M. Oropeza Salín and Enrique Castaño de la Serna (2012). Somatic Embryogenesis in Recalcitrant Plants, Embryogenesis, Dr. Ken-Ichi Sato (Ed.), ISBN: 978-953-51-0466-7, InTech, Available from:

http://www.intechopen.com/books/embryogenesis/somatic-embryogenesis-in-recalcitrant-plants

\section{INTECH}

open science | open minds

\section{InTech Europe}

University Campus STeP Ri

Slavka Krautzeka 83/A

51000 Rijeka, Croatia

Phone: +385 (51) 770447

Fax: +385 (51) 686166

www.intechopen.com

\section{InTech China}

Unit 405, Office Block, Hotel Equatorial Shanghai

No.65, Yan An Road (West), Shanghai, 200040, China

中国上海市延安西路65号上海国际贵都大饭店办公楼 405 单元

Phone: +86-21-62489820

Fax: +86-21-62489821 
(C) 2012 The Author(s). Licensee IntechOpen. This is an open access article distributed under the terms of the Creative Commons Attribution 3.0 License, which permits unrestricted use, distribution, and reproduction in any medium, provided the original work is properly cited. 